\title{
Chapter 8 \\ Beyond Boserup: The Role of Working Time in Agricultural Development
}

\author{
Lisa Ringhofer, Simron Jit Singh and Marina Fischer-Kowalski
}

\begin{abstract}
This contribution investigates the role of working time in the course of agricultural development. In so doing, we revisit Ester Boserup's $(1965,1981)$ hypothesis of increasing land productivity at the expense of declining labour productivity as a consequence of agricultural intensification in subsistence communities. We introduce a theoretical framework that centres on human time as a 'limited' biophysical resource and compare the labour burden across gender and age of four subsistence communities, one each from India, Bolivia, Nicaragua, and Laos. While Boserup's claim applies to early stages of agricultural development, we find the dynamics to change with the introduction of fossil fuel based inputs into agriculture, leading to a rise in labour productivity. Despite these improvements, we still find overall labour needs to increase with agricultural intensification. Since household labour remains largely constant during the development process, the labour burden is primarily borne by women.
\end{abstract}

Keywords agricultural change · time use - industrial transformation · land and labour intensity $\cdot$ comparative case studies

\subsection{Introduction}

Many of the world's poor live in rural environments, where their livelihoods depend on smallholder agriculture, foraging or pastoralism. ${ }^{1}$ Through regional and national development programmes, local communities increasingly aspire for

\footnotetext{
${ }^{1}$ According to the UNDP report (2008, p. 90), around three in every four people in the world who live on less than US \$1/day reside in rural areas.
}

\section{S. J. Singh $(\bowtie) \cdot$ L. Ringhofer $\cdot$ M. Fischer-Kowalski}

Institute of Social Ecology Vienna (SEC), Alpen-Adria University,

Schottenfeldgasse 29, 1070 Vienna, Austria

e-mail: simron.singh@aau.at

L. Ringhofer

e-mail: lisa.ringhofer@aau.at

M. Fischer-Kowalski

e-mail: marina.fischer-kowalski@aau.at

M. Fischer-Kowalski et al. (eds.), Ester Boserup's Legacy on Sustainability, 
modern lifestyles as they integrate their production systems into a global division of labour. In other words, the prevalent development model promotes the integration of remote communities into the market economy through industrial development approaches based on the use of fossil fuels, either directly (through the industrialisation of agricultural production) or indirectly (through specialised machinery). This appears to be the only means of escaping poverty. ${ }^{2}$

The ecological crisis of our current times cannot be understated. The crisis is global: $60 \%$ of our ecosystems have been degraded (MEA 2005; Steffen et al. 2004), and in many respects, we have exceeded the safe operating space of the planet. The distortion of the nitrogen cycle is primarily attributed to industrial agriculture and the use of fertilisers (Rockström et al. 2009). As we head towards the erosion of our own natural resource base on a global level, these current development trends run counter to the increasingly accepted notion of sustainable development. A more sustainable global future therefore requires a broader search for pathways where short- and long-term benefits for people come at the lowest possible environmental cost and the lowest possible burden and stress on individuals in terms of working time (Haberl et al. 2004, 2011).

Guided by this focus on sustainable development, our primary aim is to gain a better understanding of these transition processes "at the periphery" along with the transformative potential and impacts that are generated at the society-nature interface thereof. The conceptual framework of sociometabolic transitions (Fischer-Kowalski and Haberl 2007) is an attempt in this direction. In this context, local rural subsistence communities have been empirically investigated to understand the systemic interrelations between food production systems and the resulting environmental pressures. Comparing and contrasting these cases in terms of their demographic, sociometabolic, and agro-ecological profiles has aided the modelling of development trajectories for larger regions. A variable that is often left out from such analysis is "time use" and its link to sociometabolic transitions. While we have previously illustrated our findings on the environmental pressures triggered by the specific material, energy and land use activities in the different communities (see Fischer-Kowalski et al. 2011), the focus of this chapter is the social pressure on individuals in terms of working time and how the burden of labour changes with agricultural development.

To this end, we revisit Boserup's $(1965,1981)$ theory of agricultural change in subsistence systems and, in particular, her hypothesis on increasing area productivity at the expense of labour productivity as a consequence of technological intensification in traditional farming systems. Boserup's theory provides a framework for comparing the burden of labour among four contemporary subsistence communities in the global south that are in different stages of agricultural development.

We will first provide a brief overview of Boserup's hypothesis, followed by our sociometabolic concept of human time as a (limited) biophysical resource. What follows is a brief description of the four case studies and methods used for data collection. We then present the main findings and conclude with a brief reassessment of our hypothesis.

\footnotetext{
${ }^{2}$ These strategies are also reflected in individual countries' Poverty Reduction Strategy Papers (PRSPs) funded and designed by the World Bank.
} 


\subsection{Theoretical Assumptions, Concepts and Methods}

\subsubsection{Returning to Boserup and Introducing Sociometabolic Concepts}

Boserup's “anti-Malthusian” argument posits that even in traditional agriculture, population growth does not fully translate into an increasing demand for land for food production. Instead, technical improvements and the learning process permit increased food production on the existing land. In effect, population density rises, with the same area sustaining a greater number of individuals. Land use intensifies and returns to prior levels upon unit area increase, resulting in a rising labour input into the land. Boserup envisages a progressive series of fallow reductions driven by population pressure. As intensification progresses, i.e., from long fallow systems to multiple cropping, there is a reduction in agricultural output per man hour that accompanies the vast increase in total output per area. Thus, the higher the output per area, the more hours the farmer must work for the same amount of produce. In other words, as the benefits of fallowing are sacrificed, workloads tend to rise (due to labour-intensive tasks such as weeding, fertilising and irrigating), leading to a decline in the efficiency of labour productivity. ${ }^{3}$

Boserup's hypothesis has also come to be regarded as one of the core elements of the theory of sociometabolic regimes. Further developed by Sieferle (1997, 2001) and other authors (Fischer-Kowalski et al. 1997), the theory claims that certain modes of human production and subsistence can be broadly distinguished. Regardless of the historical timeframe and biogeographical conditions, these modes share certain fundamental systemic characteristics that derive from the way humans interact with nature. These subsistence modes or sociometabolic regimes differ according to the source of energy used and the main technologies of energy conversion. The theory distinguishes among hunters \& gatherers, the agrarian and the industrial regime. ${ }^{4}$ These three different sociometabolic regimes exhibit substantially different metabolic profiles (i.e., the quantity of materials and energy used per capita and year) and varying usage of land resources. The allocation of human time (as a limited biophysical resource contingent on demographic factors) has been integrated more recently into

\footnotetext{
${ }^{3}$ Stone (2001) maintains that the key to Boserupian intensification is that the labour costs of intensification are both necessary and sufficient to raise production concentration. They are necessary because higher production requires a proportionate increase in work and sufficient because the proportionate increase in work succeeds in raising output.

${ }^{4}$ Traditional subsistence systems, such as hunters \& gatherers and the agrarian, depend almost completely on solar energy. However, while hunters \& gatherers are "passive" users of solar energy (insofar as they live on the available resource base in their territory), agrarian regimes mainly rely on an "active" and controlled utilisation of solar energy through the use of biotechnologies and mechanical devices. In other words, peasants try to channel solar energy into a few plant species they wish to produce by changing the land cover, with the cost of an increased human labour requirement that continues to increase with agricultural intensification. The industrial sociometabolic regime, conversely, transcends the limitations of relying on available solar energy by utilising fossil fuels.
} 
this theoretical framework, with the goal of establishing a link between the intensification of land, energy, and material use and how these factors impact the need for increasing working time. Framed differently, having sufficient disposable time for engaging in social and cultural activities is a measure of well-being.

Contrary to Boserup's claim of incremental agricultural development progressing from long fallow systems to multiple cropping, the sociometabolic theory presents a different view of "transitions" between regimes: the shift between energy regimes is instead associated with a major transformation of society (such as the Neolithic and Industrial Revolutions in the past). Sociometabolic regimes are not viewed as static. Instead, they consist of a set of opportunities and constraints within which certain dynamics occur. However, if the dynamics transcend or are pushed out of the boundary conditions of the regime by exogenous forces, turbulence will ensue with an unpredictable outcome anywhere between a collapse of the social system (Leemans and Costanza 2005; Tainter 1988) and a transition into another sociometabolic regime (Fischer-Kowalski and Haberl 2007).

\subsubsection{Human Time as a Biophysical Resource}

Within our theoretical framework, human time is characterised by the following metabolic characteristics. First, and analogously to the other relevant biophysical resources (materials, energy and land), human time is a limited resource. Each individual has $24 \mathrm{~h}$ per day at his/her disposal. All human time has to be used in some manner, and preference for one activity over another is contingent on culturally prescribed means of self-maintenance and reproduction. In addition, each human lifetime hour, whether "productive" or not, requires a certain metabolic input (i.e. matter and energy). Otherwise, social conflict arises, and people starve and die. The time at one's disposal, whether one's own time or that of other individuals, is one critical indicator of freedom and power. How human time is used, therefore, is a crucial variable that determines and is determined by the system's social metabolism and its regime transitions. In some instances, societies have resisted transitions from hunting and gathering to agriculture because they were not prepared to invest the greater amount of labour time required; in contrast, the willingness of other societies to do so paved the way for agricultural transitions (Carlstein 1982; Ellen 1982).

\subsubsection{Labour Time Studies Revisited}

Research on the allocation of human labour time has a long tradition in the social sciences, especially in sociology, anthropology and economics. An underlying assumption of all these studies is that human time is a limited resource that needs to be budgeted.

Early sociological time studies dealt predominantly with exploring the social conditions of the rising working class. In the early 1930s, a whole new era of work/leisure 
studies was launched. Within the range of emerging time diary literature, Time Budgets of Human Behaviour (Sorokin and Berger 1939) provided one of the most intriguing insights into sociological and psychological stimuli for daily time use. Since the 1950s, the effects of longer working hours have become increasingly analysed through the lens of comparative time use data. Perhaps the most ambitious multi-country time use study was the Multinational Time Use Study directed by Szalai (1972) in the mid-1960s or, more recently, Gershuny's (2000) Multinational Time Budget Data Archive.

In contrast to the sociological tradition of quantifying time use, earlier anthropological studies commonly relied on qualitatively describing the "daily round" of the communities studied (Evans-Pritchard 1940; Malinowski 1935). Generally more theory-driven, notable attempts have been made to test two general theories related to time use. One is the role of "leisure time" in cultural evolution. It has been argued that development in arts and science is only possible once communities can move away from the drudgery of subsistence (Steward 1955). In contrast, Sahlins (1972), Lee (1979), and several others tried to show that leisure time is not a sufficient condition for the development of civilisation. They showed that hunters \& gatherers could meet their needs with only approximately $1-3 \mathrm{~h}$ of work each day, leaving plenty of time for leisure and idleness. This argument, highly debated by Sahlins' critics (see Bird-David 1998; Johnson 1975; Kaplan and Lancaster 2000), is neatly captured in Sahlins' classic text Stone Age Economics, whose first chapter is dedicated to the "original affluent society". The second theory that has received considerable attention in anthropology is Boserup's (1981) thesis of declining labour productivity with agricultural intensification, as previously discussed. ${ }^{5}$ While a large number of empirical studies lend support to Boserup's argument (Ellen 1982; Grigg 1974; Netting 1977, 1993; Sahlins 1972), some have rejected the "decline thesis" (Conelly 1992; Harris 1971; Hunt 2000; Padoch et al. 1985).

More recent anthropological publications on working time among horticultural societies include Johnson's $(1975,2003)$ account on the Matsigenka of Peru and Descola's (1996) study of the Achuar ethnic group in the Ecuadorian Amazon, both of which have substantially contributed to establishing a standard approach to time allocation studies. ${ }^{6}$ Some of the questions that these studies address relate to time spent on acquiring protein from hunting and fishing, the efficiency of hunting using traditional and modern weapons, the benefits of development assistance in terms of

\footnotetext{
${ }^{5}$ A different approach to labour productivity comes from the field of ecological anthropology. Rappaport's (1968) detailed monograph Pigs for the Ancestors, whilst striving to document the interdependence of cultural phenomena and biophysical variables, provides interesting data on energy expenditure during labour processes through the application of time-and-motion studies.

${ }^{6}$ Allen Johnson (1975) is considered a pioneer in terms of activity coding and classification among non-market societies. We adopted his activity coding (1975) for our own studies and restructured, added or eliminated certain activities that were not of particular relevance for our own purposes. $\mathrm{He}$ later provided an overview of systematic observation methods (Johnson and Sackett 1998). Gross (1984), one of Johnson's students, conducted interesting research on behavioural approaches in time allocation research, and Baksh $(1989,1990)$ further refined the methodological approaches for instantaneous spot check sampling.
} 
labour-saving devices, the economic importance of child labour in agrarian societies (see also Cain 1980), and the contribution of women to domestic reproduction (Antonopoulos and Hirway 2010; Gross 1984).

Within the field of economics, Becker (1965) emphasised the value of time at the household level, instigating the so-called "New Household Economics". His approach applies economic analysis to household behaviour and emphasises the importance of time in household production and consumption activities. In recent development literature, the concept of "time poverty" or "time stress" (see Hirway 2010 , p. 26) refers to the burden of work on the poor, especially on women, that restricts the choices available to them in selecting activities. ${ }^{7}$ In the wider context of sustainability, the consideration of human time as a key resource remains somewhat uncommon (the few exceptions include Giampietro 2003; Pastore et al. 1999; Ringhofer 2007, 2010, 2013; Schandl and Grünbühel 2005).

In our theoretical approach, we consider human time to be a limited and fairly evenly distributed resource, whose availability depends on the number of people within a social system and their reproduction rates. In contrast to previous time use traditions, we are primarily interested in human time as a resource on the social system level. ${ }^{8}$ At the same time, we perceive the investment of human time as a means to reproduce certain subsystems within a social system. These subsystems allow time invested for one's personal maintenance and development to be distinguished from that of time invested for household or social reproduction. The four time-relevant subsystems of the social system are the person system, the household system, the community system, and the economic system. We allocate the time spent on various activities to the respective functional subsystem that is being reproduced. To ensure comparability, the coding and classification used do not differ substantially from what is commonly found in sociological and anthropological time use studies. ${ }^{9}$

The person system functionally serves personal reproduction and includes all those activities that cannot be delegated or "outsourced" to others. It holds all of the physiologically necessary functions for a person's self-reproduction, such as sleeping and eating, and it encompasses functions for extended reproduction, such as studying, leisure activities or idleness.

The household system serves as the organisational basis for biological reproduction and fulfils the function of basic day-to-day reproduction as a group, such as child rearing and food preparation. The system also encompasses functions that ensure long-term maintenance of the household, such as repair and maintenance

\footnotetext{
${ }^{7}$ Within this concept, one important indicator of well-being is leisure, the time spent on rest and relaxation.

${ }^{8}$ From the perspective of ecological economics, Pastore et al. (1999) conducted a land-time budget (LTB) analysis for various villages in rural China, examining demographic variables, land availability and land use, time availability, labour time use and cash flows. The LTB analysis was one of the first approaches treating land and time use as an opportunity or constraint at the social system level.

${ }^{9}$ The time use categories developed for statistical monitoring of the European Union (Eurostat 2001,2007 ) have been largely followed in our four cases.
} 
work. The household system is typically organised as an exchange of unpaid labour according to the socio-cultural norms regulating age and gender roles in society.

The community system on the next higher functional level contributes to the reproduction of reciprocal relationships and shared beliefs as well as political decision making. In non-industrial societies, the community system may be regarded as a predecessor of more specialised systems, such as politics, religion or the judicial subsystem.

The economic system extends beyond the household, even though part of its function consists of supplying households and individuals with life-sustaining commodities (with economic "food provision" sometimes difficult to distinguish from household "food preparation"). The economic system reproduces the society, in a division of labour and functional interdependence beyond the household, and manages most of what was described as social metabolism above. Under modern conditions, the economic system typically functions on the basis of paid labour. Under premodern conditions, economic activities may simply be an additional function of households or communities.

\subsection{Description of the Cases}

\subsubsection{Introducing Trinket, Campo Bello, Sabawas, and Nalang}

To test Boserup's theory, we classify and position the four cases by - to use Boserup's terminology - their degree of "agricultural intensification". We do this by examining basic demographic data and a few agro-ecological indicators of food production and consumption. If we consider population density to be an indicator of population pressure on land, Trinket has by far the lowest density ( $0.11 \mathrm{cap} / \mathrm{ha})$ and the lowest rate of population growth. The other three communities, Campo Bello, Sabawas and Nalang, all have similar population densities (approximately $0.40 \mathrm{cap} / \mathrm{ha}$ ) and fairly high population growth rates (2.5-4\% annually). Food system information also provides insight into the relative position of each of the cases. With respect to food production, we find a gradual increase from Campo Bello to Sabawas to Nalang, with Nalang also having the highest percentage of nutritional energy derived from agriculture. Fishing and foraging contribute to the food intakes in all four communities. While the percentages in Campo Bello, Sabawas, and Nalang range from 7 to $16 \%$, Trinket derives almost $70 \%$ of its food energy from fishing and foraging. Thus, in terms of food production, Trinket stands out as a community that is predominantly dependent on hunting and gathering as the mode of subsistence. From this analysis, we have provisionally ranked the cases along a "Boserupian axis" from Trinket to Nalang (Table 8.1).

Trinket Island is located in the Nicobar archipelago (India) and had 399 inhabitants in 2001. Because it can only be accessed by canoe or diesel-engine boat at high tide, the island has remained quite isolated, and the people of Trinket continue to live 


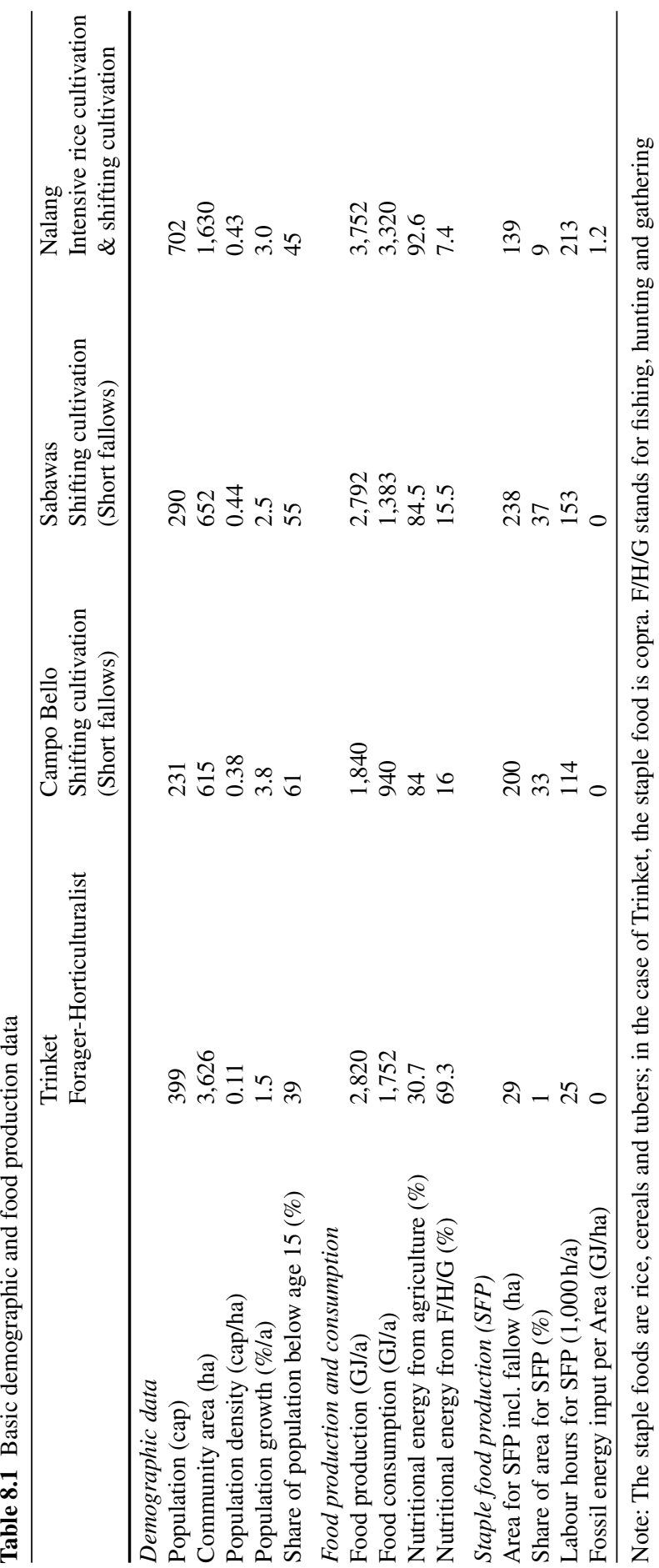


relatively traditional lifestyles. The primary activities of the local population are fishing and gathering, the growing of coconuts and the bartering of copra (dehydrated coconuts) in exchange for market commodities. Some families also cultivate food gardens, which they maintain with simple tools, such as sickles, axes, and spades. Despite low agricultural production - the total area for staple food production amounts to only one-third to one-fifth of the areas used in the other communities-fossil energy inputs are by far the highest in Trinket. This is a direct result of a state-induced subsidy programme for transport infrastructure that promotes the sale of cheap diesel and kerosene (Singh 2003; Singh and Grünbühel 2003; Singh and Schandl 2003; Singh et al. 2001).

The indigenous community of Campo Bello (Bolivia) is situated in the Bolivian Amazon plains with 231 inhabitants in 2004. About one-third of the community's total area comprises the agricultural area for staple food production. Rice, maize, and manioc are typically grown using only simple technology, such as machetes, sickles, hoes, and rice seeders for sowing rice. Much of the rice is sold at the market for cash immediately after the rice harvest, while plantains are generally marketed throughout the year. The local diet is complemented by protein sources from fishing and foraging that account for about one-fifth of the total nutritional energy inputs into the system. Still largely secluded and self-contained, the village has witnessed a number of development projects introduced by the local administration and non-governmental agencies (Ringhofer 2007, 2010, 2013).

The remote indigenous community of Sabawas (Nicaragua) with a population of 290 people in 2008 is located in the territory officially named Mayangna Sauni As. In the early 1980s during the Contra War, the whole territory was abandoned, and Sabawas remained uninhabited for almost 10 years until repatriation began in 1994. Almost $40 \%$ of the community's total area is used for staple food production. The agricultural activity includes the farming of upland rice, plantains, banana, maize, and velvet beans with simple machetes, spades, hoes, and axes. Because transport opportunities are limited, the marketing of these crops is erratic, and crop cultivation is largely subsistence based. The importance of farming is reflected by the high nutritional intake from agriculture, at nearly $85 \%$. The local diet is complemented by proteins from fishing and foraging that account for the remainder of the total nutritional energy inputs into the system (Ringhofer et al. 2010).

The multi-ethnic community of Nalang (Laos) with a population of 702 people in 2001 combines swidden agriculture with permanent paddy rice production. Despite having similarly sized areas for staple food production, the energetic returns in Nalang are twice as high as in Sabawas and almost three times higher than in Campo Bello. This is attributable in part to fossil fuel input in the form of motor-ploughs, accounting for $1.2 \mathrm{GJ} / \mathrm{ha}$. Greater ease of transport following the construction of a road in the 1980s also triggered increased market integration: cucumber was introduced as an important cash crop during the dry season, and traditional buffalo rearing is gradually losing importance. Although buffaloes continue to be reared in Nalang, the arrival of the motor-plough in the mid-1990s has diminished the agricultural need for them. In terms of meat production, buffaloes are gradually being replaced by cattle, largely because of the shorter maturing times of cattle (Mayrhofer-Grünbühel 2004). 


\subsubsection{Methods of Data Collection on Time Use}

The data collection methods vary between the case studies. Meanwhile, a more systematic methodology has been developed containing comparable time use indicators (Ringhofer 2010, Singh et al. 2010), and considerable efforts have been made to transform the time use data from earlier studies into the new scheme.

In the case of Trinket, we used "time-frame" analysis focussing only on certain activities observed repeatedly (a sample size of 3-5 observations for each activity). The duration of these activities and the participants (in terms of gender and age) were recorded. These activities were then weighted according to their annual frequency and used to calculate the average daily hours. Interviews were conducted for the household activities. Time use for the person system was calculated as a residual. As the most recent empirical studies, the time use analyses for the communities of Campo Bello and Sabawas were conducted systematically, with people observed for days during their waking hours. In Campo Bello, the sample consisted of 12 male and 13 female days (each including four children between the ages of 6 and 15). In addition to these samples, a total of 112 spot checks were performed, thereby obtaining two more person days. In Sabawas, the sample consisted of 13 male and 11 female days (including three children between the ages of 6 and 15 and 2 adults over the age of 60) who were "shadowed" at different times of the year, thus covering seasonal differences. Household interviews and direct observation were used for cross-checking. Average time use and standard deviations were calculated for all four subsystems mentioned above. In the case of Nalang, both of the above-mentioned methods were used. The sample size was 23 females and 23 males (including 10 girls and 11 boys). In addition to observation, the context and meaning of the activities performed were validated by interviews in all cases. To obtain system level data, the frequency of these processes across the members of the community and the year was estimated and used for weighing.

\subsection{Findings}

To what extent does Boserup's (1965, 1981) claim still hold and aid our understanding of today's agricultural transitions? And what can we learn about the overall burden and stress in terms of working time across gender and age? Using the ranking of our cases along the "Boserupian axis" discussed in the previous sections, we organise the findings in the following way. First, we examine land and labour productivity and seek to test Boserup's claim of the dynamics of agricultural intensification. Second, we present the labour investments in the economic and household systems along with the resulting social distribution of the labour burden in the different communities. 


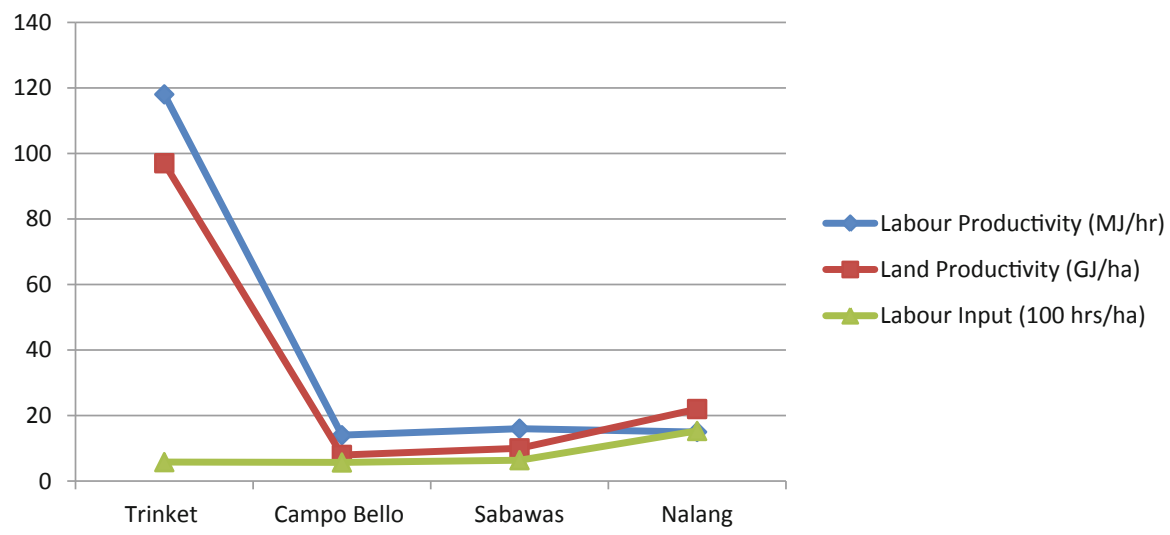

Fig. 8.1 Labour and land productivity in staple food production

\subsubsection{Land and Labour Productivity}

Judging from the results shown in Fig. 8.1, our cases do not seem to conform with Boserup's hypothesis of agricultural intensification. As the first example, Trinket is characterised by land and labour productivity conditions that are substantially more favourable than those of the other cases. Both land productivity (how much land is required to produce a certain amount of nutritional energy) and labour productivity (how much work is required to realise this energy harvest) are far higher than in any of the other communities. ${ }^{10}$ Considered from another perspective, it appears that no incremental evolutionary pathway of agricultural intensification would lead from a sociometabolic system of hunting and gathering like that of Trinket, however atypical, to a system resembling those of the other communities. With such high productivity levels, it would seem completely irrational to alter course in favour of a more intensive production mode, considering declining returns on land and labour. Thus, a sociometabolic system like that in Trinket will either persist or collapse rather than being gradually transformed into an agrarian system similar to those in the other cases. In effect, the hypothesis of distinct sociometabolic regimes is supported by this example: communities such as Trinket adhere to a sociometabolic regime of hunters $\&$ gatherers, however atypical, with no continuous, non-disruptive pathway leading from this regime to an agrarian regime. It takes a major transformation, a "transition", for a community to transcend this mode of subsistence (Fischer-Kowalski et al. 2011, p. 153 f.).

Campo Bello and Sabawas are both "traditional" (Boserup 1981) production systems insofar as fossil fuel-based inputs and animal traction are not used for any of

\footnotetext{
${ }^{10}$ With the exception of some pig rearing, the inhabitants of Trinket do not engage in agricultural tasks. Instead, they grow coconut palms and exchange dried coconut flesh (copra) for rice on the market. The high land and labour productivity of Trinket therefore reflects the good exchange conditions of copra to rice.
} 
Table 8.2 Daily time investment per adult for all four subsystems

\begin{tabular}{lllll}
\hline & \multicolumn{3}{l}{ Average Adult 16-60 (h/d) } & \\
\cline { 2 - 5 } & Trinket & Campo Bello & Sabawas & Nalang \\
\hline Total population size & 399 & 231 & 290 & 702 \\
Population size 16-60 & 244 & 91 & 121 & 356 \\
Person System $(P S)$ & 18.45 & 13.21 & 13.00 & 14.34 \\
Household system $(H S)$ & 3.23 & 3.79 & 3.70 & 3.68 \\
Care for dependents & 0.00 & 1.59 & 1.50 & 0.46 \\
Food preparation & 1.09 & 1.07 & 1.00 & 0.69 \\
House building & 0.00 & 0.26 & 0.25 & 1.43 \\
Repair/maintenance work & 0.16 & 0.34 & 0.35 & 0.00 \\
Domestic chores & 1.98 & 0.64 & 0.60 & 1.10 \\
Economic system $(E S)$ & 1.19 & 4.69 & 4.75 & 5.85 \\
Agriculture/horticulture & 0.07 & 2.32 & 2.25 & 3.06 \\
Hunting & 0.00 & 0.46 & 0.45 & 0.00 \\
Fishing & 0.58 & 0.35 & 0.30 & 0.44 \\
Gathering & 0.00 & 0.17 & 0.20 & 0.15 \\
Trading & 0.39 & 0.43 & 0.45 & 0.00 \\
Wage work & 0.00 & 0.27 & 0.25 & 1.46 \\
House garden & 0.02 & 0.21 & 0.25 & 0.00 \\
Handicraft & 0.00 & 0.41 & 0.40 & 0.13 \\
Animal husbandry & 0.14 & 0.02 & 0.20 & 0.61 \\
Community system $(C S)$ & 1.13 & 2.32 & 2.55 & 0.12 \\
Annual labour time ES (h/a) & 434 & 1,711 & 1,733 & 2,135 \\
Daily labour time HS + ES (h/d) & 4.42 & 8.48 & 8.45 & 9.54 \\
\hline
\end{tabular}

their agricultural activities. Nalang, however, uses some fossil fuel input (1.2 GJ/ha), in the form of motor-ploughs for rice production. Considering the use of fossil fuels, the relationships among the three communities would most likely comply with the Boserupian hypothesis: with intensifying food production, there is indeed increased yield per unit area, resulting in increased labour input and declining labour productivity. Without fossil fuels, Nalang would likely have a much lower labour productivity than that shown in Fig. 8.1. The use of fossil fuel-based and labour-saving technologies in agriculture, which are not considered in Boserup's theory, reduces the need for human labour and makes human labour hours appear more productive.

\subsubsection{Overall Labour Time Investment in the Different Communities}

How do these intensification dynamics relate to the overall distribution of working time in the four communities? Alternatively, what conclusions can be drawn regarding the sharing of the labour burden across gender and age? To address these questions, Table 8.2 presents an overview of the daily hours invested in the individual subsystems, i.e., the person system, the household system, the economic system, and the community system. 
While the person system draws by far the most time resources, with sleep representing the greatest component, the overall time investments in the community system are relatively low in all four communities. ${ }^{11}$ The time resources associated with the economic system steadily increase from the agrarian community of Campo Bello to Sabawas to Nalang. Trinket's labour requirements for the upkeep of the economic system are much lower, amounting to only one-fourth of the relative time investments of Campo Bello and Sabawas and one-fifth of that of Nalang. Trinket's daily working time for the average adult (16-60 years) is slightly over $1 \mathrm{~h}$, accounting for $434 \mathrm{~h}$ annually. This is barely more than a quarter of the workload common in OECD countries. As for the "traditional" agrarian cases, 4-6h are required daily from every adult for the upkeep of the economic system, which amounts to annual economic working times of 1,711 h per adult in Campo Bello, 1,733 h in Sabawas and $2,135 \mathrm{~h}$ in Nalang. These values are comparable to the approximately 1,800 annual hours per economically active ${ }^{12}$ in the US and Japan and are above the averages for the European Union (Groningen database 2005).

Not surprisingly, we find that agro-horticultural activities represent the predominant component in the fairly similar agrarian communities of Campo Bello, Sabawas and Nalang, accounting for about half of all the time resources invested in the economic system. Trinket's agricultural labour time, however, constitutes a mere $6 \%$ of total labour time inputs. Interestingly, despite Trinket's extremely low time investment in agriculture (the agricultural labour requirements in Campo Bello and Sabawas are approximately 30 times greater than that of Trinket, whereas Nalang's labour requirements are 40 times greater), the local nutritional energy returns from agriculture (Table 8.1) account for a quite substantial $30 \%$, which is roughly onethird of the agricultural energy harvests of the agrarian communities. Although Trinket and Nalang invest about the same daily time resources for fishing and gathering, Nalang receives less than one-tenth of its nutritional energy from these sources, while Trinket's returns from these activities cover almost $70 \%$ of their total nutritional requirements. Cash-producing activities, e.g., wage work, trading and the production of saleable handicraft, require only about half as much time than agricultural activities in the agrarian cases, while Trinket's investment in trading is about four times higher than in agriculture. Wage work draws more than $2 \mathrm{~h}$ of an adult's day in Nalang, while in the other agrarian communities, it is far less significant than other cash-producing activities, such as the production and sale of handicrafts as an additional source of income.

\footnotetext{
${ }^{11}$ What influences the time investment into the community system, and what differences (in terms of social integration and cohesion, for example) arise from the amount of time spent? Unfortunately, our data on community time investment cannot be used to address these questions because of uncertainties in measurement and classification.

${ }^{12}$ One should be aware of the difference between "average per adult" (which includes all individuals over the age of 14) and "average per economically active", which in OECD countries is about half the adult population over 14 years of age. Therefore, these working hours in subsistence agriculture communities are really very high!
} 


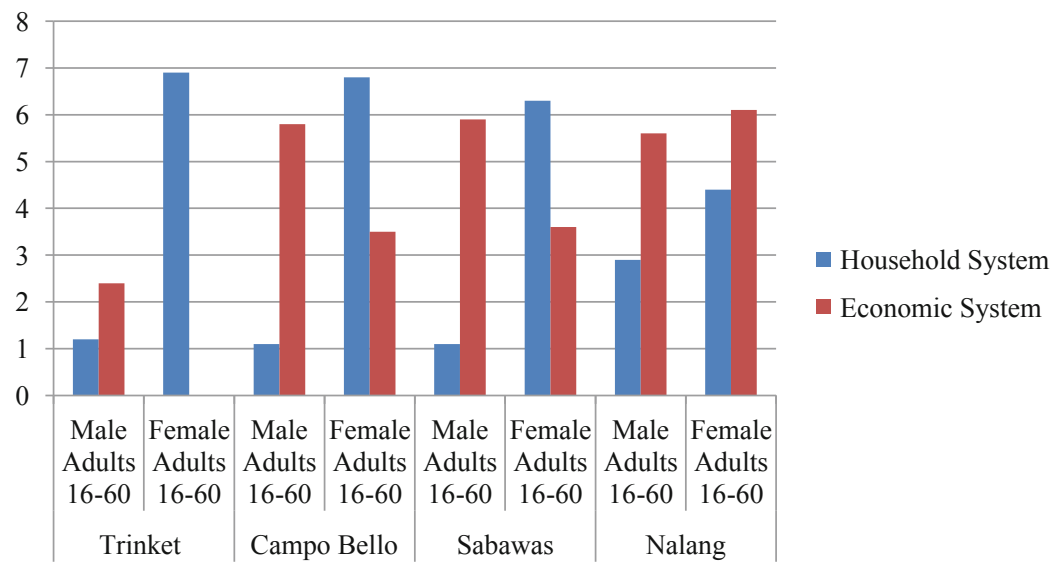

Fig. 8.2 Gender differences in labour time

One interesting finding is that household labour draws similar time investments in all four cases, accounting for $3.2-3.7 \mathrm{~h}$ per average adult. ${ }^{13}$ Most of this time is invested in the day-to-day reproduction of the household, including child care, food preparation and domestic chores. As described in the section below, this involves a constantly higher labour burden for women throughout the development trajectory.

\subsubsection{Gender Differences in Labour Time}

With respect to gender, a tentative interpretation of our data shows that the upkeep of the household system predominantly remains in the hands of women throughout "agrarian development". In Trinket, Campo Bello, and Sabawas, household labour draws 6-7 h from an adult woman's daily time resources, while male labour contribution to the household system accounts for little more than $1 \mathrm{~h}$ per day. In contrast to the other cases, Nalang's household labour seems to be more evenly distributed between the sexes (Fig. 8.2). In terms of the specific types of tasks, we find a fairly similar division of labour chores between men and women. While female labour largely entails activities for the system's day-to-day reproduction, male labour tends to contribute to the long-term maintenance of the household (e.g., house-building, repair, and maintenance work).

As shown in Table 8.3, overall labour in the economic system increases with "agrarian development", and judging from our data, so does a woman's labour contribution. With the exception of Trinket, where women do not invest any labour in economic activities (and men's work is limited to little more $2 \mathrm{~h}$ a day), we find a substantial almost 3-h increase in a woman's workload from the fairly similar agrarian communities of Campo Bello and Sabawas to the more "agriculturally intense" community of Nalang. Though male labour is the predominant component

\footnotetext{
${ }^{13}$ More detailed data reveal a stagnant 2.1 daily hours per inhabitant.
} 


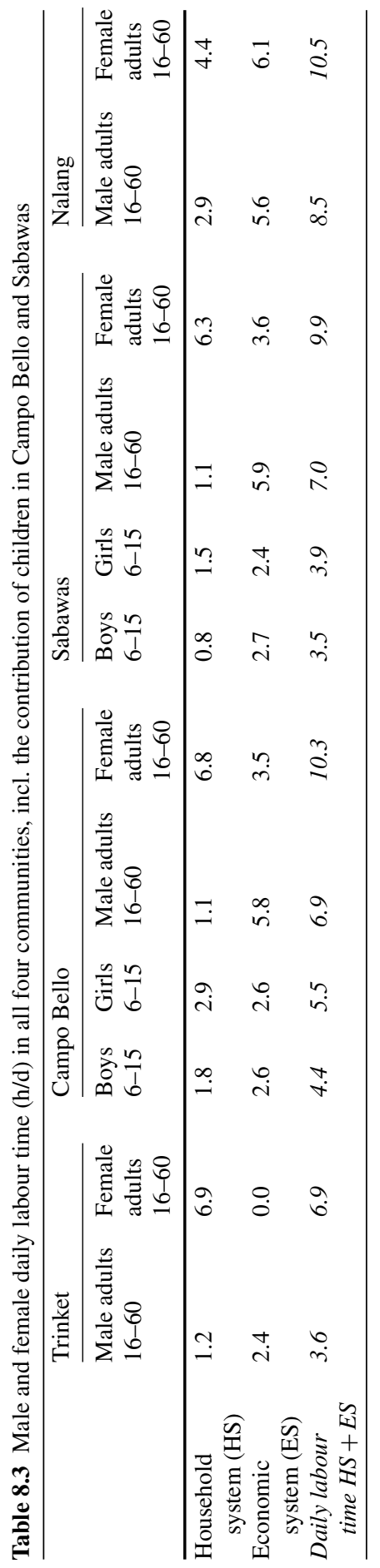


in agriculture in Campo Bello and Sabawas, the role of women in agriculture is important and highly valued. Women contribute about two-thirds of their overall economic labour time to agro-horticultural tasks. The small remainder is invested in subsistence fishing and gathering (hunting is solely ascribed to men in all of the communities) and market involvement (through the production of saleable handicraft, trading and wage work). In Nalang, the only community that uses fossil fuel-driven technology for agricultural production (i.e., motor-plough), a woman's contribution to the daily economic labour time is slightly higher than that of her male counterpart. This finding illustrates that the labour-saving motor-plough may have alleviated the workload of men in rice production, while many other labour-intensive agricultural tasks continue to be performed by women. ${ }^{14}$

If we define the daily working time as the total amount of time invested in the household and economic system, a steady increase of working time for both sexes would be expected for "agricultural intensification". In all of these stages, however, we find women working longer hours than men. For men, the low daily work burden of $3.6 \mathrm{~h}$ in Trinket cannot be sustained by agrarian production systems. In the more "traditional" (Boserup 1981) production systems embodied by Campo Bello and Sabawas (insofar as fossil fuel-based inputs and animal traction are not used), the daily male labour requirement nearly doubles. The use of agricultural technologies may relieve a man's economic work burden in Nalang; his contribution to the longterm maintenance of the household, however, increases. Similarly for women, a 7-h workday (Trinket) cannot be sustained with increased agricultural production when her contribution levels off at approximately $10 \mathrm{~h}$ a day. When women continuously work longer hours, they have less time available to spend for personal reproduction activities, such as studying, leisure, or idleness. Detailed data from Campo Bello show that adult women get less sleep than men, which may contribute to illness and premature death in the long run.

One interesting, albeit tentative, finding is that even communities with a relatively low labour burden per individual (such as Trinket) tend to display the same pattern of labour allocation by gender as more labour-intensive agrarian communities. However low the economic labour burden may be for men, a woman's share in household labour is fairly consistent throughout "agricultural development".

\subsubsection{The Contribution of Children to Labour Time}

Finally, we examine the contribution of child labour in the different communities. ${ }^{15}$ Table 8.4 shows that the children's share in the overall time budget of the communities

\footnotetext{
${ }^{14}$ A similar situation is observed in Campo Bello, where the application of rice seeders, as opposed to traditional rice planting, saves up to 12 days of labour in annual rice production. These technologies, however, are solely handled by men, while women continue to engage in laborious traditional planting, weeding and harvesting (Ringhofer 2010).

${ }^{15}$ Child labour in Trinket was observed but not systematically registered. Therefore, the contribution of children to labour processes is based on estimations. Additionally, this section focuses instead on the cases of Campo Bello and Sabawas, where child labour contribution was most systematically observed.
} 
Table 8.4 Children's share in community working time

\begin{tabular}{lllll}
\hline & Trinket & Campo Bello & Sabawas & Nalang \\
\hline Population size & 399 & 231 & 290 & 702 \\
Population growth (cap/a) & 1.5 & 3.8 & 2.5 & 3 \\
Number of children below 15 & 155 & 137 & 159 & 318 \\
Share of population below 15 (\%) & 39 & 59 & 55 & 45 \\
$\begin{array}{l}\text { Children's share in the total community labour } \\
\text { time investment (\%) }\end{array}$ & 39 & 61 & 51 & 45 \\
\hline
\end{tabular}

Table 8.5 Children's daily investment of household and economic labour in Campo Bello and Sabawas $(\mathrm{h} / \mathrm{d})$

\begin{tabular}{|c|c|c|c|c|}
\hline & \multicolumn{2}{|c|}{ Campo Bello } & \multicolumn{2}{|l|}{ Sabawas } \\
\hline & Boys 6-15 & Girls $6-15$ & Boys 6-15 & Girls 6-15 \\
\hline Household system $(H S)$ & 1.8 & 2.9 & 0.8 & 1.5 \\
\hline Care for dependents & 0.5 & 1.5 & 0.2 & 0.6 \\
\hline Food preparation & 0.2 & 0.5 & 0.0 & 0.3 \\
\hline House building & 0.0 & 0.0 & 0.1 & 0.0 \\
\hline Repair/maintainance work & 0.2 & 0.2 & 0.2 & 0.2 \\
\hline Domestic chores & 0.9 & 0.7 & 0.3 & 0.4 \\
\hline Economic system (ES) & 2.6 & 2.6 & 2.7 & 2.4 \\
\hline Agriculture/horticulture & 0.8 & 0.2 & 0.8 & 0.3 \\
\hline Hunting, fishing and gathering & 1.1 & 1.5 & 1.2 & 1.6 \\
\hline Trading & 0.0 & 0.3 & 0.0 & 0.0 \\
\hline Handicraft & 0.6 & 0.4 & 0.5 & 0.3 \\
\hline Animal husbandry & 0.1 & 0.2 & 0.2 & 0.2 \\
\hline Daily labour time $H S+E S$ & 4.4 & 5.5 & 3.5 & 3.9 \\
\hline
\end{tabular}

is $61 \%$ in Campo Bello, $51 \%$ in Sabawas, $45 \%$ in Nalang and $39 \%$ in Trinket. Thus, in terms of available "live" hours, children below the age of 15 play a major role in all four communities.

We find the highest ratio of child labour in Campo Bello (61\%), in which the percentage of the population under 15 years of age is also highest. More detailed data reveal that about one-third of the community's total labour invested in the household system is contributed by children aged 6-15 years. This is more than double the contribution of children to household labour in Sabawas, where the percentage of the population under 15 years of age is almost as high as in Campo Bello. It should be noted that in Campo Bello, children of both sexes engage in reproductive household labour such as child care and food preparation until about the age of 10, when they gradually become socialised into their gender-assigned roles. This pattern is less prevalent in Sabawas, where reproductive household tasks are mostly carried out by girls and female adults. Girls in Sabawas invest twice as much time as boys in the daily reproduction of the household system (Table 8.5).

The economic system draws similar time resources from boys and girls in Campo Bello and Sabawas. Agricultural activities appear to be a predominantly male domain in both villages. In Campo Bello, a boy starts to cultivate his own fields at around 12 years of age, even if it seems to be more of an educational activity. In Sabawas, a boy's 
contribution to agriculture tends to involve assistance tasks, such as the transport of plantains or the fetching of seeds (see Ringhofer 2010). Hunting and fishing is carried out in a more playful manner. ${ }^{16}$ For girls, fishing and gathering represents the predominant component of their time investment in the economic system.

Clearly, children do lighter work and may do it less efficiently than adults. Nevertheless, approximately one-third of the total labour hours in Campo Bello and Sabawas are contributed by children. As documented by Fischer-Kowalski et al. (2010), children in Campo Bello also spend approximately the same fraction of their day working as the average inhabitant.

In addition to making up a smaller percentage of the populations of Nalang and Trinket, children in these communities also appear to have a lower labour burden. Due to their substantially lower share in household and economic work, they have the opportunity to spend the remainder of their day on person system activities, such as studying and personal recreation.

These results, however selective, lend support to Cain's (1981) argument that agricultural communities with higher demographic proportions of children place a high labour burden on them. Framed differently, communities in which children are considered of high use value in terms of labour contribution (either for technological or cultural reasons) tend to have more children. We find that the community with the highest percentage of the population under 15 years of age $(61 \%)$ also has the highest share of child labour (Campo Bello). Sabawas, the community with the second highest child population ( $55 \%$ ), also places a relatively high labour burden on their children. Nalang's children, in contrast, are less burdened with labour, particularly household labour. Finally, Trinket has the lowest demographic reproduction rate and the lowest share of child labour.

\subsection{Conclusions}

Rural development and poverty alleviation programmes worldwide have succumbed to the ideology of agricultural change through the deliverance of technology. While this has indeed helped maintain larger populations by boosting food production per area, this has not come without ecological and social costs. Boserup's hypothesis of declining labour productivity is indeed supported up to a certain point in agricultural development. As such, increasing workloads on rural communities in which women and children are subject to ever higher exploitation is evident. However, the dynamics change with the introduction of fossil fuel-based technology, thereby countering Boserup's linear claim. With the introduction of fossil fuel-based technology, a reverse trend of increasing labour productivity is observed. However, this does not mean that the overall burden of work for the community is reduced or more evenly

\footnotetext{
${ }^{16}$ Children's play (e.g., play hunting or play food processing) in traditional subsistence societies is widely documented (Bock 2002; Caro 1988; Fagen 1981) as a safe strategy that imparts more skills that will increase productivity in the future compared to time spent performing directly productive tasks.
} 
distributed across gender and age. Fossil fuel-based agricultural technologies (such as tractors, tillers, and threshers) are used by men and reduce their workload, while other labour-intensive tasks (such as sowing, weeding, and spreading manure) continue to be performed by women and children (see also Gooch, Chap. 10 in this volume).

We have seen that the change in the energy system causes a transition from one sociometabolic regime to another. This is evident not only in energy use per capita but also in the overall working time of a community. Trinket's time investment in the economic system is only a quarter of the time investment of the others. The leisure experienced by hunting and gathering modes of production is hardly comparable to the toil of the agrarian system, with its severe consequences on the female and child populations. The difference in time use across the four cases arises from the changing workload in the economic/subsistence sector, and this workload, as Boserup posits, increases with agricultural intensification-but only up to the point where fossil fuels come into play. The labour invested in household chores remains more or less constant across agricultural intensification and across sociometabolic regimes. Thus, the cost of the additional burden is actually a trade-off on personal reproduction and care primarily borne by women (and to some extent, also by children).

Development trajectories are not simply a matter of economic well-being. Ecological and social sustainability for present and future generations ought to include a broader view of the quality of life. To this end, we need to have a better understanding of the dynamic and systemic relationship between key biophysical resources, for which time is indeed a crucial variable along with its equitable distribution across gender and age.

Open Access This chapter is distributed under the terms of the Creative Commons Attribution Noncommercial License, which permits any noncommercial use, distribution, and reproduction in any medium, provided the original author(s) and source are credited.

\section{References}

Antonopoulos, R., \& Hirway, I. (2010). Unpaid work and the economy: Gender, time use and poverty in developing countries. New York: Palgrave Macmillan.

Baksh, M. (1989). Spot observations technique in time allocation research [Part 1]. CAM: Cultural Anthropology Methods Newsletter, 1, 1-3.

Baksh, M. (1990). Spot observations technique in time allocation research [Part 2]. CAM: Cultural Anthropology Methods Newsletter, 2, 6-7.

Becker, G. S. (1965). A theory of the allocation of time. Economic Journal, 75(299), 493-517.

Bird-David, N. (1998). Beyond "The Original Affluent Society": A culturalist reformulation. In J. Gowdy (Ed.), Limited wants-unlimited means: A reader on hunter-gatherer economics and the environment (pp. 115-138). Washington, DC: Island Press.

Bock, J. (2002). Evolutionary demography and intrahousehold time allocation: Schooling and children's labor among the Okavango Delta peoples of Botswana. American Journal of Human Biology, 14, 206-221.

Boserup, E. (1965). The conditions of agricultural growth: The economics of agrarian change under population pressure. Chicago: Aldine/Earthscan. 
Boserup, E. (1981). Population and technological change: A study of long-term trends. Oxford: Basil Blackwell.

Cain, M. T. (1980). The economic activities of children in a village in Bangladesh. In H. P. Binswanger (Ed.), Rural household studies in Asia (pp. 218-247). Singapore: Singapore University Press.

Cain, M. T. (1981). Extended kin, patriarchy, and fertility. Liege. Belgium: International Union for the Scientific Study of Population, Committee on Comparative Analysis of Fertility.

Carlstein, T. (1982). Time resources, society and ecology. Volume 1: Preindustrial societies. London: George Allen \& Unwin.

Caro, T. M. (1988). Adaptive significance of play: Are we getting closer? Trends in Ecology and Evolution, 3, 50-53.

Conelly, T. (1992). Upland development in the tropics: Alternative economic strategies in a Philippine frontier community. London: Routledge.

Descola, P. (1996). In the society of nature: A native ecology in Amazonia. Cambridge: Cambridge University Press.

Ellen, R. (1982). Environment, subsistence and system: The ecology of small-scale social formations. Cambridge: Cambridge University Press.

Eurostat. (2001). Material use indicators for the European Union, 1980-1997. Economy-wide material flow accounts and balances and derived indicators of resource use. Working Paper No. 2/2001/B/2. Prepared by S. Bringezu \& H. Schütz. Luxembourg: European Commission/ Eurostat.

Eurostat. (2007). Economy-wide material flow accounting: A compilation guide. Luxembourg: European Statistical Office.

Evans-Pritchard, E. E. (1940). The Nuer: A description of the modes of livelihood and political institutions of a Nilotic people. Oxford: Oxford University Press.

Fagen, R. (1981). Animal play behavior. New York: Oxford University Press.

Fischer-Kowalski, M., \& Haberl, H. (2007). Socioecological transitions and global change: Trajectories of social metabolism and land use. Cheltenham: Edward Elgar.

Fischer-Kowalski, M., et al. (1997). Gesellschaftlicher Stoffwechsel und Kolonisierung von Natur: Ein Versuch in Sozialer Ökologie. Amsterdam: Gordon \& Breach Fakultas.

Fischer-Kowalski, M., Singh, S. J., Ringhofer, L., Grünbühel, C. M., Lauk, C., \& Remesch, A. (2010). Sociometabolic regimes in indigenous communities and the crucial role of working time: A comparision of case studies. Social Ecology Working Paper, No. 121. Vienna, Austria: IFF Social Ecology.

Fischer-Kowalski, M., Singh, S. J., Lauk, C., Remesch, A., Ringhofer, L., \& Grünbühel, C. M. (2011). Sociometabolic transitions in subsistence communities: Boserup revisited in four comparative case studies. Human Ecology Review, 18(2), 147-158.

Gershuny, J. (2000). Changing times: Work and leisure in post-industrial societies. Oxford: Oxford University Press.

Giampietro, M. (2003). Multi-scale integrated analysis of agroecosystems: An integrated assessment. Boca Raton: CRC Press LLC.

Grigg, D. B. (1974). The agricultural systems of the world. Cambridge: Cambridge University Press.

Groningen database. (2005). Groningen Growth and Development Centre (GGDC).

Gross, D. R. (1984). Time allocation: A tool for the study of cultural behavior. Annual Review of Anthropology, 13, 519-558.

Haberl, H., Fischer-Kowalski, M., Krausmann, F., Weisz, H., \& Winiwarter, V. (2004). Progress towards sustainability? What the conceptual framework of material and energy flow accounting (MEFA) can offer. Land Use Policy, 21(3), 199-213.

Haberl, H., Fischer-Kowalski, M., Krausmann, F., Martinez-Alier, J., \& Winiwarter, V. (2011). A socio-metabolic transition towards sustainability? Challenges for another great transformation. Sustainable Development, 19(1), 1-14.

Harris, M. (1971). Culture, man, and nature: An introduction to general anthropology. New York: Thomas Y. Crowell Company 
Hirway, I. (2010). Understanding poverty: Insights emerging from time use of the poor. In R. Antonopoulos \& I. Hirway (Eds.), Unpaid work and the economy: Gender, time use and poverty in developing countries (pp. 22-50). New York: Palgrave Macmillan.

Hunt, R. C. (2000). Labor productivity and agricultural development: Boserup revisited. Human Ecology, 28(2), 251-277.

Johnson, A. (1975). Time allocation in a Machiguenga community. Ethnology, 14, 310-321.

Johnson, A. (2003). Families of the forest: The Matsigenka Indians of the Peruvian Amazon. Berkley: University of California Press.

Johnson, A., \& Sackett, R. (1998). Direct systematic observation of behaviour. In H. R. Bernard (Ed.), Handbook of methods in cultural anthropology (pp. 301-330). Walnut Creek: AltaMira.

Kaplan, H., \& Lancaster, J. B. (2000). The evolutionary economics and psychology of the demographic transition to low fertility: Evolutionary biology and human social behaviour: 20 years later. In L. Cronk, N. Chagnon, \& W. Irons (Eds.), Adaptation and human behaviour: An anthropological perspective (pp. 283-322). New York: Aldine de Gruyter.

Lee, R. B. (1979). The! Kung San: Men, women and work in a foraging society. London: Cambridge University Press.

Leemans, R., \& Costanza, R. (2005). Integrated history and future of people on Earth (IHOPE). IHDP Newsletter, 2/2005, 4-5.

Malinowski, B. (1935). Coral gardens and their magic. London: Routledge.

Mayrhofer-Grünbühel, C. (2004). Resource use systems of rural smallholders: An analysis of two Lao communities. Doctoral thesis, University of Vienna, Austria.

MEA (Millennium Ecosystem Assessment). (2005). Ecosystems and human well-being. Washington, DC: World Resources Institute.

Netting, R. M. (1977). Cultural ecology. San Francisco: Cummings Publishing Company.

Netting, R. M. (1993). Smallholders, householders: Farm families and the ecology of intensive, sustainable agriculture. Stanford: Stanford University Press.

Padoch, C., Chota Inuma, J., De Jong, W., \& Unruh, J. (1985). Amazonian agroforestry: A market-oriented system in Peru. Agroforestry Systems, 3, 47-58.

Pastore, G., Giampetro, M., \& Ji, L. (1999). Conventional and land-time budget analysis of rural villages in Hubei province, China. Critical Review in Plant Sciences, 18(3), 331-357.

Rappaport, R. A. (1968). Pigs for the ancestors: Rituals in the ecology of a New Guinea people. New Haven: Yale University Press.

Ringhofer, E. (2007). The Tsimane in their environment: a socio-ecological analysis of the environmental relations of an indigenous community in the Bolivian Amazon. Doctoral thesis, University of Vienna, Austria.

Ringhofer, L. (2010). Fishing, foraging and farming in the Bolivian amazon: On a local society in transition. New York: Springer.

Ringhofer, L. (2013). Introducing Functional Time Use (FTU) analysis: A gender-sensitive approach to labor time. Gendered Perspectives on International Development, Working Paper Series Nr. 34. East Lansing, MI: Center for Gender in Global Context, Michigan State University.

Ringhofer, L., Rivera Arboleda, F., Delgado Dolmus, O., \& Davis Pérez, F. (2010). The Mayangna Model Baraknin Yulni: A conservation-based approach to food sovereignty, socio-economic welfare and human development. Vienna: Hilfswerk Austria International.

Rockström, J. W., et al. (2009). A safe operating space for humanity. Nature, 461, 472-475.

Sahlins, M. (1972). Stone age economics. New York: Aldine de Gruyter.

Schandl, H., \& Grünbühel, C. M. (Guest Eds.). (2005). Southeast Asia in transition. International Journal of Global Environmental Issues, 5(3/4), 115-118.

Sieferle, R. P. (1997). Rückblick auf die Natur: Eine Geschichte des Menschen und seiner Umwelt. Munich: Luchterhand.

Sieferle, R. P. (2001). The subterranean forest: Energy systems and the industrial revolution. Cambridge: The White Horse Press.

Singh, S. J. (2003). In the sea of influence: A world system perspective of the Nicobar islands. Lund: Lund University Press. 
Singh, S. J., \& Grünbühel, C. M. (2003). Environmental relations and biophysical transitions: The case of Trinket islands. Geografiska Annaler, Series B. Human Geography, 85B(4), 187-204.

Singh, S. J., \& Schandl, H. (2003). Socio-economic metabolism in the Nicobar islands: Empirical research in society-nature interactions. In B. Benzing \& B. Herrmann (Eds.), Exploitation and overexploitation in societies past and present. IUAES-Intercongress 2001 Goettingen (pp.169-184). Münster: LIT Publishing House.

Singh, S. J., Grünbühel, C. M., Schandl, H., \& Schulz, N. (2001). Social metabolism and labour in a local context: Changing environmental relations on Trinket Island. Population and Environment, 23(1), 71-104.

Singh, S. J., Ringhofer, L., Haas, W., Krausmann, F., Lauk, C., \& Fischer-Kowalski, M. (2010). Local studies manual: A researcher's guide for investigating the social metabolism of rural systems. Social Ecology Working Paper, No. 120. Vienna: IFF Social Ecology.

Sorokin, P., \& Berger, C. (1939). Time-budgets of human behaviour. London: Harvard University Press.

Steffen, W., et al. (Eds.). (2004). Global change and the Earth system: A planet under pressure. Berlin: Springer.

Steward, J. (1955). Handbook of South American Indians. Washington, DC: Smithsonian Institution, Bureau of American Ethnology.

Stone, G. D. (2001). Theory of the square chicken: Advances in agricultural intensification theory. Asia Pacific Viewpoint, 42(2/3), 163-180.

Szalai, A. (1972). The use of time: Daily activities of urban and suburban populations in twelve countries. The Hague: Mouton.

Tainter, J. A. (1988). The collapse of complex societies. Cambridge: Cambridge University Press.

UNDP (United Nations Development Programme). (2008). Human development report 2007/2008. Fighting climate change: Human solidarity in a divided world. http://hdr.undp.org/en/reports/global/hdr2007-2008/. Accessed 15 Jan 2012. 